\title{
Pellon kasvipeitteisyyden teknologia muuttuvassa ilmastossa - maaperämikrobien ekosysteemipalvelujen hyödyntäminen
}

\author{
Ansa Palojärvi $^{1)}$, Timo Sipilä ${ }^{1) 2}$, Kim Yrjälä ${ }^{2)}$ ja Laura Alakukku ${ }^{3)}$ \\ ${ }^{1)}$ MTT Kasvintuotannon tutkimus, 31600 Jokioinen, ansa.palojarvi@mtt.fi \\ ${ }^{2)}$ Biotieteiden laitos,00014 Helsingin yliopisto, timo.p.sipila@helsinki.fi, kim.yrjala@helsinki.fi \\ ${ }^{3)}$ Maataloustieteiden laitos, 00014 Helsingin yliopisto, laura.alakukku@helsinki.fi
}

\section{Tiivistelmä}

Maatalous kohtaa ilmastonmuutoksen myötä entistä suurempia ympäristöhaasteita. Eroosio- ja ravinnekuorma vesistöihin kasvaa, mikäli talvet muuttuvat ennustetulla tavalla lauhemmiksi ja sateisemmiksi. Talviaikainen kasvipeitteisyys suojaa maan pintaa vähentäen eroosio- ja ravinnehuuhtoumariskiä. Kevätkylvöisten kasvien viljelyssä kasvukauden ulkopuolinen kasvipeitteisyys voidaan toteuttaa sekä vähentämällä syysmuokkausta (mm. kevennetty muokkaus, suorakylvö sänkeen keväällä) että lisäämällä viljelykiertoon monivuotisia kasveja. Muokkausta kevennettäessä edellisen vuoden kasvustojäte voi hidastaa maan lämpenemistä ja kuivumista keväällä, sekä luoda suotuisat olosuhteet maa- ja kasvinjätelevintäisille kasvitaudeille. Kasvipeitteisyyden ympäristöhyöty vähenee, mikäli torjunta-aineiden käyttötarve lisääntyy.

Peltomaassa on yleensä jossain määrin luontaista kykyä estää taudinaiheuttajien kehittymistä ja kasvua. Syynä ovat muut maaperän mikrobit: tietyt maaperämikrobit voivat tuottaa toisten mikrobien kasvua estäviä ns. antagonistisia yhdisteitä ja mikrobiston monimuotoisuuden sinänsä on todettu vahvistavan maan kykyä tukahduttaa sienitauteja. Maaperän mikrobiston koostumuksen ratkaisevana tekijänä on viljelytekniikka, joka vaikuttaa maamikrobien ravintoon ja elinympäristön olosuhteisiin. Tällaisia viljelyteknisiä keinoja ovat mm. maan muokkaus ja viljelykierto.

Vuonna 2009 aloitettiin hanke 'Tuotannon kestävyys muuttuvissa ilmasto-oloissa - teknologiset ratkaisut ja maaperäbiologisten ekosysteemipalvelujen hyödyntäminen', jonka tavoitteena on kehittää innovatiivistä ja käytännön peltoviljelyyn soveltuvaa maatalouden ympäristöteknologiaa peltojen kasvipeitteisyyden lisäämiseksi samalla hyödyntäen maaperämikrobiston ekosysteemipalveluja tautimikrobien tukahduttamiseksi luontaisin menetelmin ja kasvijätteen toivotunlaiseksi hajotukseksi. Hankkeessa on monitieteinen tutkimusryhmä MTT:n ja Helsingin yliopiston tutkijoita maatalouden ympäristöteknologiasta, ympäristöbiotekniikasta, biologiasta ja mikrobiologiasta.

Posterissa annetaan yleiskuva hankkeesta (ks. myös posteri Knuutila ym.) sekä esitellään tarkemmin kasvitautien luontaiseen tukahduttamiseen eli tautisuppressiivisuuteen keskittyvää osahanketta.

Asiasanat: maaperämikrobisto, tautisuppressiivisuus, kasvitaudit, suorakylvö, kyntö 


\section{Johdanto}

Maatalous kohtaa ilmastonmuutoksen myötä entistä suurempia ympäristöhaasteita. Eroosio- ja ravinnekuorma vesistöihin kasvaa, mikäli talvet muuttuvat ennustetulla tavalla lauhemmiksi ja sateisemmiksi. Kasvipeitteisyys suojaa maan pintaa vähentäen eroosio- ja ravinnehuuhtoumariskiä. Kevätkylvöisten kasvien viljelyssä kasvukauden ulkopuolinen kasvipeitteisyys voidaan toteuttaa sekä vähentämällä syysmuokkausta (mm. kevennetty muokkaus, suorakylvö sänkeen keväällä) että lisäämällä viljelykiertoon monivuotisia kasveja. Muokkausta kevennettäessä edellisen vuoden kasvustojäte voi hidastaa maan lämpenemistä ja kuivumista keväällä, sekä luoda suotuisat olosuhteet maa- ja kasvinjätelevintäisille kasvitaudeille. Kasvipeitteisyyden ympäristöhyöty vähenee, mikäli torjunta-aineiden käyttötarve lisääntyy. Maaperän mikrobiston ns. ekosysteemipalveluja ovat kasvustojätteen hajotus ja maaperän tautisuppressiivisuus eli luontainen kyky estää taudinaiheuttajien kehittymistä ja kasvua (Janvier ym. 2007). Maaperän mikrobiston koostumukselle on keskeistä viljelytekniikka, joka vaikuttaa elinympäristön olosuhteisiin ( $\mathrm{mm}$. maan muokkaus, viljelykierto).

Viljelyskasvien kasvitautien määrä vaihtelee eri maaperissä, jotkut maaperät altistavat kasvit taudeille (Kondusiivinen) ja toiset maat tukahduttavat kasvitauteja (Suppressiivinen). Suppressiivinen maaperä on sellanen, missä kasvitaudin määrä ja oireet pysyvät alhaisina huolimatta taudin aiheuttajan läsnäolosta, sopivasta isäntäkasvista ja taudin kehitykselle suotuisista olosuhteista. Maaperän mikrobiyhteisön on havaittu olevan tärkeä maan suppressiivisten ominaisuuksien kannalta $(\mathrm{mm}$. de Boer ym. 2003). Ei kuitenkaan tarkasti tiedetä millä mikrobiryhmillä tai mikro-organismeilla on vaikutusta kasvitautien suppressiivisuuteen. Maaperän fungistaasi tarkoittaa ilmiötä, jossa sienen itiöiden itäminen ja rihmaston kasvu on rajoitetumpaa kuin voisi olettaa sienten kasvun perusteella samankaltaisissa olosuhteissa, lämpötilassa, kosteudessa ja pH:ssa (Lockwood 1977). Fungistaasiilmiön tiedetään osittain korreloivan kasvitautien suppressiivisuuden kanssa.

Tutkimuksen tavoitteena on kehittää innovatiivistä ja käytännön peltoviljelyyn soveltuvaa maatalouden ympäristöteknologiaa peltojen kasvipeitteisyyden lisäämiseksi samalla hyödyntäen maaperämikrobiston ekosysteemipalveluja tautimikrobien tukahduttamiseksi vaihtoehtoisena menetelmänä kemialliselle torjunnalle ja kasvijätteen toivotunlaiseksi hajotukseksi.

\section{Aineisto ja menetelmät}

Tutkimus on jaettu kolmeen osahankkeeseen. Osahanke 1 tarkastelee kasvipeitteisyyden ja muokkausintensiteetin vaikutuksiin maaperän fysikaalisiin ominaisuuksiin, joilla on merkitystä peltomaan viljeltävyydelle ja mikrobistolle. Osahankkeessa hyödynnetään automaattisia mittausmenetelmiä ja mallinnusta (ks. posteri Knuutila ym.). Osahanke 2 keskittyy argoteknologisiin mahdollisuuksiin edistää sellaisten maaperämikrobien esiintymistä ja toimintaa, jotka tukahduttavat maa- ja kasvijätelevintäisiä kasvitaudinaiheuttajia. Tavoitteena on minimoidaan kemiallisten torjuntaaineiden tarve. Lisäksi selvitetään kasvitautien tukahduttamiskyvyn mekanismeja. Osahanke 3 selvittää kasvipeitteisen peltomaan sienten monimuotoisuutta ja aktiivisuutta, sekä mahdollisuuksia tehostaa sienten avulla kasvijätteen hajotusta toivotulla tavalla. Hankkeessa hyödynnetään MTT:n pitkäaikaisia kenttäkokeita muokkausintensiteetistä ja viljelykierroista. Hanke kuuluu MTT:n Muuttuva ilmasto ja maatalous -tutkimusohjelmaan ja HY:n Ympäristöntutkimuksen ja -opetuksen yksikön (HENVI) Globaalin ympäristömuutoksen ohjelmaan.

Tässä esityksessä kerrotaan tarkemmin osahankkeesta 2.

\section{Maaperän fungistaasi ja kasvitautien suppressiivisuus}

Työssä analysoidaan muokkausmenetelmien vaikutusta maaperän suppressiivisuuteen ja kondusiivisuuteen. Tutkitaan maaperän mikrobiyhteisöjä tavoitteena kuvata mitkä mikro-organismit ovat tyypillisiä suppressiivisille maille ja minkälaisia mikrobeja löytyy kondusiivista maista ja miten näihin voitaisiin vaikuttaa muokkausmenetelmien avulla. Mikrobiyhteisöjen rakenne, monimuotoisuus ja avainlajikoostumus kuvataan käyttämällä DNA-merkkigeenianalyysiä, jossa maaperästä eristetään kokonais-DNA. Eristetystä DNA:sta monistetaan merkkigeenejä, joiden avulla voidaan tunnistaa maan mikro-organismit ja selvittää mikrobiyhteisön rakenne. 
Fungistaasia mitataan peltomaista käyttäen rihmaston kasvutestiä testiä petrimaljalla (de Boer ym. 1998) ja itiöiden itävyys testiä nuclepore ${ }^{\mathrm{TM}}$ polykarbonaatti-membraanilla testattavan maan päällä. Peltomaiden kosteus säädetään $85 \%$ maan vedenpidätyskyvystä. Konrollina toimii hiekka $(0,5-$ $1,2 \mathrm{~mm})$ ja 50/50 hiekka/Montmorilloniiti -seos. Mallikasvitautisieninä toimivat Fusarium culmorum ja Bipolaris sorokiniana. Fungistaasin ohella tutkitaan myös kasvitautien suppressiivisuutta in vivo altistuskokeessa mallikasvina ohran Annabell-lajike ja kasvitautina Fusarium culmorum.

\section{Maaperän mikrobiyhteisoiden kuvaaminen}

Maaperän kokonais-DNA eristetään käyttäen PowerSoil DNA eristys kittiä (MO BIO Laboratories). Kokonaismikrobiyhteisöt monistetaan käytäen 16S rRNA geenialukkeita 27f ja 1492r (Weisburg ym. 1991). Geelipuhdistetut merkkigeenit (Wizard SV gel and PCR Clean-up system, Promega) kloonataan pGEMT vektoriin (pGEMT vector system, Promega) ja transformoidaan kompetentteihin DH5a E. coli soluihin. Mikrobiyhteisökirjastot seulotaan mikrobiryhmäspesifisillä alukkeilla (Mühling ym. 2008; Nechitaylo ym. 2009). Maan muokkausmenetelmien ja suppressiivisuuden kannalta kiinnostavat mikrobiryhmät monistetaan suoraan kokonais-DNA:sta ja niiden osuutta tutkitaan DNA-sormenjälkimenetelmillä kuten RFLP,T-RFLP ja sekvensointi. Avain mikrobiryhmät kvantitoidaan käyttäen qPCR analyysiä.

\section{Johtopäätökset}

Tutkimuksen tuloksia voidaan hyödyntää hallinnossa, opetuksessa, neuvonnassa ja käytännön viljelyssä kohdennettaessa viljelytoimenpiteitä ympäristöllisin perustein, sekä kehitettäessä kestäviä ja ympäristöä vähemmän kuormittavia viljelykäytäntöjä. Tulosten avulla voidaan tuotteistaa uusia mikrobituotteita, joilla edistetään maatalouden sopeutumista muuttuvaan ilmastoon.

\section{Kirjallisuus}

de Boer, W., Klein Gunnewiek, P.J.A. \& Woldendorp, J.W. 1998. Suppression of hyphal growth of soilborne fungi by dune soils from vigorous and declining stands of Ammophila arenaria. New Phytologist 138: $107-116$.

de Boer, W., Verheggen, P., KlainGunnewiek, P.J.A., Kowalchuk, G.A. \& van Veen, J.A. 2003. Microbial community composition affects soil fungistasis. Appl Environ Microbiol 69: 835-844.

Janvier, C., Villeneuve, F., Alabouvette, C., Edel-Hermann, V., Mateille, T. \& Steinberg, C. 2007. Soil health through soil disease suppression: which strategy from descriptors to indicators? Soil Biology \& Biochemistry 39: 1-23.

Lockwood JL. 1977. Fungistasis in soils. Biological Reviews 52: 1-43.

Mühling, M., Woolven-Allen, J., Murrell, J.C. \& Joint, I. 2008. Improved group-specific PCR primers for denaturing gradient gel electrophoresis analysis of the genetic diversity of complex microbial communities. ISME Journal 2: 379-392.

Nechitaylo, T.Y., Yakimov, M.M., Godinho, M., Timmis, K.N., Belogolova, E., Byzov, B.A., Kurakov, A.V., Jones, D. \& Golyshin, P.N. 2009. Effect of the earthworms Lumbricus terrestris and Aporrectodea caliginosa on bacterial diversity in soil. Microb Ecol. In press.

Weisburg, W.G., Barns, S.M., Pelletier, D.A. \& Lane, D.J. 1991. 16S ribosomal DNA amplification for phylogeneticstudy. J Bacteriol 173: 697-703. 